\title{
BONUSES IN THE MAIL
}

When $E T$ was hardly more than a rumour, unsolicited material began to arrive in Cambridge. Even now, more than a year and four issues later, complete typescripts come in from people who have not yet seen a copy, but have heard about the magazine and want to be involved.

Such unsolicited articles were and remain a good omen, but they unfortunately tend not to fit the format and style of the magazine. The ideas may be excellent, but the material may be too long; too specialized and/or too academic.

There is a change in the air now, however, among potential contributors who have seen the magazine. Completed typescripts are shorter, snappier and easier to handle; better still, first contact may be in the form of an idea and some specimens, which can be an enormous editorial boost. Given the quarterly nature of $E T$ and the need for long-term planning, a 4,000-word bolt from the literary blue is not only too space-consuming but likely also to cut across two or three items already in the pipeline. A concise proposal instead is less work for everybody concerned and stands a far better chance of success.

Nothing that arrives in the editorial post-bag is ignored. This issue, for example, has benefited enormously from unexpected bonuses in the mail; the calibre and panache of many letters and contributions are heartening, as is the 90 -something-\% positive response to $E T$ itself.

As a consequence, the occasional brickbat stands out quite starkly when it does come (See across).

But in the words of one correspondent: 'You need subscribers, not just applause.' That is incontrovertible. Subscriptions are rising steadily, but with more subscribers in these early stages we can do more and can involve more people in the general enterprise. It is already clear that one issue of $E T$ reaches far more than one person. It is also clear that people are telling their friends and colleagues about the magazine - which is the best possible publicity. But if you like $E T$ 's format, content and outlook, why not give a Christmas, Hanukkah, New Year, birthday or other subscription to someone with similar tastes and interests to your own?

It is good to finish our first year with the sheer scope of ET4. Our authors are all masters of what they write about: Bob Ilson on American and British, Vernon Noble on changes in British English, Connie Eble on the journal American Speech, John Haycraft on EFL, Josef Skvorecky on literary translation, Bill Beavis on the sea and ships, and Manfred Görlach on a most remarkable linguistic hobby. I finish off the ABC of World English, the newest and fullest grammar of English ever is reviewed, and there is a plethora of pidgins and other assorted Englishes to sample. More, in Post \& Mail and David Crystal's Usage, we have the fullest range so far of readers' comments and feedback.

Tom McArthur

The editorial policy of English Today is to provide a focus or forum for all sorts of news and opinion from around the world. The points of view of individual writers are as a consequence their own, and do not reflect the opinion of the editorial board. In addition, wherever feasible, ET leaves unchanged the orthography (normally British or American) and the usage of individual contributors, although the editorial style of the magazine itself is that of Cambridge University Press.

\section{A Call for Papers}

In $E T$ 's files we have cuttings/clippings from a wide range of British and North American newspapers, and a scattering of material from many other sources. If readers would care to add to our files by sending in occasional (titled and dated) material from their.local newspapers, etc., or even the odd complete sample of a specially interesting periodical, this would be a great help in widening the range of usage which we can quote in From Our Files.

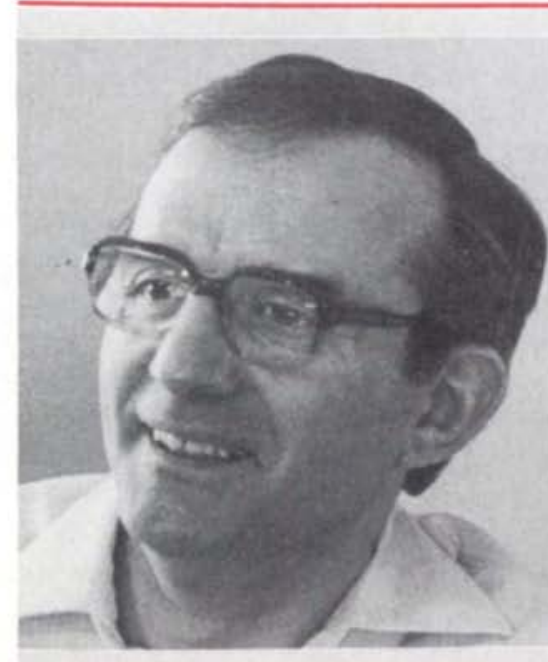

TOM MCARTHUR was born in Glasgow in 1938. A graduate of both Glasgow and Edinburgh universities, he has been in turn an officer-instructor in the British Army, a school-teacher in the Midlands of England, Head of English at the Cathedral School, Bombay, organizer of courses for overseas students at the University of Edinburgh. and associate professor of English at the Université du Québec. He has written for many periodicals, including The Birmingham Mail, The Times of India, and The Scotsman. His publications in linguistics, lexicography and language teaching include the Longman Lexicon of Contemporary English, A Foundation Course for Language Teachers, The Written Word, and the co-editing of Languages of Scotland. He is married with three children.
Letters to the editor should be addressed either to a branch of Cambridge University Press (for forwarding), or directly to:

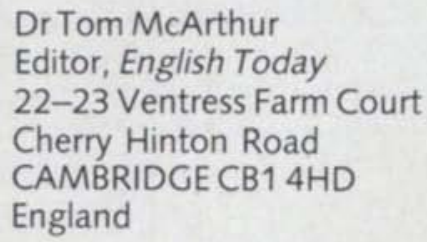

Dr Tom McArthur Editor, English Today 22-23 Ventress Farm Court Cherry Hinton Road CAMBRIDGE CB1 4HD England 